\title{
Physical and chemical characterization of the pulp of different varieties of avocado targeting oil extraction potential
}

\author{
Caracterização física e química da polpa de diferentes variedades de abacate \\ visando o potencial para extração de óleo
}

\author{
Edinéia Dotti MOOZ ${ }^{\star}$, Natália Moreno GAINO ${ }^{1}$, Marilis Yoshie Hayashi SHIMANO ${ }^{1}$, \\ Rodrigo Dantas AMANCIO'1, Marta Helena Fillet SPOTO ${ }^{1}$
}

\begin{abstract}
The aim of this study was to evaluate the physicochemical properties of avocado pulp of four different varieties (Avocado, Guatemala, Dickinson, and Butter pear) and to identify which has the greatest potential for oil extraction. Fresh avocado pulp was characterized by moisture, protein, fat, ash, carbohydrates and energy contents were determined. The carotenoids and chlorophyll contents were determined by the organic solvent extraction method. The results showed significant differences in the composition of the fruit when varieties are compared. However, the striking feature in all varieties is high lipid content; Avocado and Dickinson are the most suitable varieties for oil extraction, taking into account moisture content and the levels of lipids in the pulp. Moreover, it could be said that the variety Dickinson is the most affected by the parameters evaluated in terms of overall quality. Chlorophyll and carotenoids, fat-soluble pigments, showed a negative correlation with respect to lipids since it could be related to its function in the fruit. The varieties Avocado and Dickinson are an alternative to oil extraction having great commercial potential to be exploited thus avoiding waste and increasing farmers' income.

Keywords: Persea Americana; nutritional value; carotenoids; chlorophyll.
\end{abstract}

\section{Resumo}

O objetivo deste estudo foi avaliar as características físico-químicas da polpa de abacate de quatro diferentes variedades (Avocado, Guatemala, Dicson e Manteiga), visando identificar qual possui maior potencial para extração de óleo. A polpa de abacate fresca foi caracterizada através da determinação dos teores de umidade, proteína, lipídios, cinzas, carboidratos e valor energético. Os teores de carotenoides e clorofila foram determinados através do método de extração com solvente orgânico. Os resultados mostram diferenças significativas na composição dos frutos, quando se confrontam as variedades. No entanto, a característica marcante em todas as variedades é o alto teor de lipídios, sendo as variedades Avocado e Dicson mais indicadas para a extração de óleo, levando-se em conta os teores de lipídios nas polpas e as menores porcentagens de umidade. Além disso, pode-se dizer que a variedade Dicson é aquela que sofre maior influência dos parâmetros analisados sobre a sua qualidade global. A clorofila e os carotenoides, pigmentos lipossolúveis, mostraram correlação negativa em relação aos lipídios, podendo esta estar associada a sua função no fruto. As variedades de abacate Avocado e Dicson são alternativas para extração de óleo, apresentando grande potencial comercial a ser explorado, podendo-se evitar dessa forma o desperdício e aumentar a renda dos produtores. Palavras-chave: Persea Americana; valor nutricional; carotenoides; clorofila.

\section{Introduction}

The avocado tree is a fruit plant originated in the Americas, especially Mexico and Central America, belonging to the Lauraceae family and Perseal genus (MARANCA, 1980; KOLLER, 1992).

It is one of the most productive plants per unit of cultivated area. A large number of varieties of avocado are found in different regions of Brazil, whose fruits have varied chemical composition, especially in terms of levels of lipids in the pulp.

Fruits with high levels of lipids in the pulp can be important raw material for oil extraction (TANGO; TURATTI, 1992).
Since it is a tropical fruit, avocado stands out for its high nutritional value and it is beneficial to growth and development. However, its ripening process is different from other species of fruit.

Being a climacteric fruit, it completes its maturation after harvest (VIEIRA; VIÉGAS, 1994), with intense physiological and biochemical changes and high production of carbon dioxide and ethylene, which triggers the ripening process (MARTÍNEZ-ROMERO et al., 2003). Due to these characteristics, ripening control is essential to increase the shelf life after harvest (KLUGE et al., 2002). 
The avocado is useful in human nutrition as a source of various nutrients and especially as source of energy and monounsaturated fatty acids. At about $70 \%$ of total fruit weight correspond to the pulp (FAVIER et al., 1999) with an average of $6.94 \mathrm{~g}$ of carbohydrates, $17.34 \mathrm{~g}$ of fat, $2.08 \mathrm{~g}$ of proteins, $2.72 \mathrm{~g}$ of fibers, in $100 \mathrm{~g}$ of fresh pulp (TUCUNDUVA, 2002).

Sterols, alcohols, tocopherols, and carotenoids are also present. Most of the fat found in this fruit is monounsaturated, and its consumption helps reduce total cholesterol, LDL cholesterol, and triglycerides while increasing HDL cholesterol levels (SALGADO, 2005).

With regard to carotenoids, $100 \mathrm{~g}$ of pulp of commercial varieties show an average of $24 \mathrm{mcg}$ of alpha-carotene, $62 \mathrm{mcg}$ of beta-carotene, $28 \mathrm{mcg}$ of beta-cryptoxanthin, and 271 mcg of lutein + zeaxanthin (UNITED..., 2010), considered the first three pro-vitamin A components. Carotenoids are important because they act in the prevention of chronic non-communicable diseases such as cancer and heart disease, among others.

In many countries, avocado is consumed as a vegetable in the form of salads, with onions and cheese, as soup, with salt and pepper, or even as a canned product (TEIXEIRA et al., 1992). In Brazil, it is often used in sweet dishes, fresh with cream or sugar, shakes, and ice-creams, but it can also be used in savory dishes such as guacamole (OLIVEIRA et al., 2003).

Mexico is the country that leads the production of avocados in the world; Brazil is the third largest world producer. The state of São Paulo is the largest domestic producer, accounting for more than $50 \%$ of production. The state of Minas Gerais is the second, followed by Parana and Espirito Santo (AGRIANUAL, 2009).

The main varieties that supply the domestic market are: Simmonds, Barbieri, Collison, Quintal, Fortuna, Breda, Reis, Solano, Imperador, Ouro Verde, and Campinas. The varieties for export and/or industrialization are Tatuí, Fuerte, Hass, and Wagner (PEIXOTO et al., 1995).

The avocado pulp has been used to produce commercial oils to substitute for olive oil, with which it shares similarities such as being extracted from the fruit pulp and having some physicochemical properties such as fatty acid composition, especially oleic acid (CANTO; SANTOS; TRAVAGLINI, 1980; BLEINROTH; CASTRO, 1992; SOARES et al., 1992; TANGO; TURATTI, 1992; TANGO; CARVALHO; SOARES, 2004). These oils are rich in omega- 9 fatty acids, which may have beneficial effects to health in relation to the prevention of cardiovascular diseases (AHMED; BARMORE, 1990; REBOLLO et al., 1998).

Compared with other sources of vegetable oils, avocado oil is characterized by showing high levels of monounsaturated fatty acids, oleic (18:1 n-9) and palmitoleic acids (16:1 n-9), low contents of polyunsaturated linoleic acid (18:2n-6), relatively high content of saturated palmitic acid (16:0), and low content of stearic acid (18:0) (TURATTI; CANTO 1985; SOARES et al., 1992).

An important characteristic of this fruit is the high content of unsaponifiable matter ( 1 to $4 \%$ ) when compared with that of common edible oils (TURATTI; CANTO, 1985).
Phytosterols are important because they are key components of plant cell membranes, such as cholesterol is a key component of animal cell membranes. They are known as plant sterols and are found in higher concentrations in fatty foods like oil, nuts, and seeds (HICKS; MOREAU, 2001).

Sterols are a predominant group among those present in unsaponifiable matter of avocado, and the main constituent of this group is the $\beta$-sitosterol, comprising about $80 \%$ of the sterols present in unsaponifiable matter. Other types of sterols also present are campesterol, stigmasterol, and cholesterol (LAW, 2000).

These phytosterols have a similar chemical structure to cholesterol, differing only in their side chain lengths, and this structure similarity explains the ability of phytosterols to reduce cholesterol (HICKS; MOREAU, 2001). The $\beta$-sitosterol is the main sterol present in foods, especially avocados.

Tocopherols are commonly used as antioxidants (MURCIA et al., 2001) because they give the hydrogen from the hydroxyl group to the peroxyl radical. They can also inhibit lipid peroxidation by sequestering the singlet oxygen (KAMAL-ELDIN; APPELQVIST, 1996; FUKUZAWA et al., 1998) and free radicals (SCHULER, 1990).

Many studies on the beneficial effects of tocopherols have already been performed. The literature reports antidiabetic and anti-inflammatory effects as well as beneficial effects against Alzheimer's disease and prevention of atherosclerosis and hypertension (SALDEEN; SALDEEN, 2005).

Saldeen and Saldeen (2005) showed that the mixture of $\delta$-, $\gamma$-and $\alpha$-tocopherol has better antioxidant and anti-inflammatory effect than only $\alpha$-tocopherol in animal models and in a limited number of preliminary clinical investigations.

Lu et al. (2005) demonstrated that lipophilic extracts of avocado containing tocopherols and carotenoids significantly inhibit the in vitro proliferation of PC-3 and LNCaP prostate cancer cells.

Avocado oil from Margarida variety proved to be an excellent source of vitamin A (in the form of a-tocopherol); $100 \mathrm{~mL}$ of the fruit comply with $60 \%$ of the recommended daily requirements for adults (DANIELI, 2006).

Given the above and the alternative use of avocado oil mainly for food purposes, the objective of this study was to evaluate the physicochemical properties of the avocado pulp of four different varieties and to identify which has greatest potential for oil extraction.

\section{Material and methods}

The experiment was conducted at the Bromatology Laboratory of the Department of Agribusiness, Food and Nutrition - "Luiz de Queiroz" School of Agriculture - ESALQ/ USP. The experiment used avocados of varieties Avocado, Guatemala, Dickinson, and Butter pear purchased from different retail outlets of Piracicaba-SP and packed until maturation point. 
The fresh avocado pulp was characterized by physicochemical methods, according to official AOAC method (ASSOCIATION..., 1995) through the determination of moisture, protein, fat, and ash contents in triplicate for each sample. Carbohydrates were obtained by difference $100 \%$ - (\%protein $+\%$ moisture $+\%$ lipid $+\%$ ash $)$. The results were expressed as percentages and compared with the Brazilian Table of Food Composition (TACO, version 2, second edition) (UNIVERSIDADE..., 2006), Brazilian Table of Food Composition - USP (TBCAUSP 5.0) (UNIVERSIDADE..., 2010), and the National Nutrient Database for Standard Reference - United States Department of Agriculture (USDA).

The total energy value (Kcal) was calculated by the formula: $\mathrm{Kcal}=((\operatorname{Carb} \times 4)+(\operatorname{Prot} \times 4)+(\operatorname{Lip} \times 9))$. The respective value was multiplied by 4.18 to obtain the energy value in $\mathrm{KJ}$.

The contents of chlorophyll and carotenoids were determined by the extraction method with organic solvent, according to Lichtenthaler (1987). In triplicate, $2 \mathrm{~g}$ of each sample were immersed in $18 \mathrm{~mL}$ of acetone $80 \%$, stirred, and centrifuged at $3000 \mathrm{rpm}$ for 10 minutes. The quantification was done using a spectrophotometer.

The statistical analysis was performed using the SAS statistical program (Statistical Analysis System) (STATISTICAL..., 1999) and the means were compared by the Tukey's test. For correlation and Analysis of Main Components, the PC-ORD statistical program was used (MCCUNE; MEFFORD, 1997).

\section{Results and discussion}

Table 1 shows the results for the proximate composition of avocados varieties Avocado, Guatemala, Dickinson, and Butte pear. The average of the four varieties was compared with food composition tables available in literature.

Different values are observed among the avocado varieties and the values found in tables of food composition. The difference between the avocado pulp compositions varies with cultivars, maturity stage and geographic location of plant growth. However, the hallmark of all varieties is the high level of lipids. Its quality is comparable to olive oil; however, this raw-material has not been fully commercially exploited.

A correlation between moisture and lipid has also been observed due to the fact that the sum of these substances corresponds to most part of the fruit pulp, with the sole exception of butter pear variety, which showed higher amount of carbohydrate in relation to lipids.

The correlation found in this study between contents was also observed by other authors. Tango, Carvalho and Soares (2004) in a study on the characterization of avocados, targeting the potential for oil extraction, observed that the fresh fruit pulps, which were low in fat, had higher percentages of moisture, contrary to what was found for pulps with higher lipid levels.

Ahmed and Barmore (1990) reported negative correlation between moisture and oil contents of the fruits analyzed. In Chile, Olaeta and Undurraga (1995) evaluated moisture and oil contents of eight avocado varieties and found negative correlations between 0.92 and 0.98 , and from simple regression models, they estimated the percentage of oil and maturation index of avocados.

According to Tango, Carvalho and Soares (2004), the high moisture content in fresh pulp constitutes the main obstacle to obtaining avocado oil, affecting the extraction yield and production cost.

Thus, the most suitable varieties for oil extraction, taking into account the lipid levels in the pulp and the moisture contents, would be Avocado and Dickinson.

Table 2 shows the differences between the varieties with regard to proximal composition, energy, and contents of carotenoids and chlorophyll in the pulp of the four avocado varieties studied. No significant statistical differences were observed among the avocado varieties with the same letter in each nutrient analyzed.

It appears that the avocado is a high energy food (95.27 to $130.21 \mathrm{kcal} 100 \mathrm{~g} \mathrm{~g}^{-1}$ ) if compared with other tropical fruits. However, it has a high nutritional value, since it is rich in

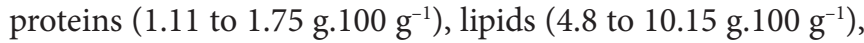
and carbohydrates ( 7.3 to $\left.11.54 \mathrm{~g} .100 \mathrm{~g}^{-1}\right)$. It also has bioactive substances such as carotenoids ( 1.72 to $5.65 \mathrm{mg} \cdot \mathrm{mL}^{-1}$ ), which are fat-soluble substances.

The results showed that there are significant differences in the composition of the fruit when varieties are compared. With regard to moisture, the varieties Dickinson and Butter pear

Table 1. Proximate composition (g.100 g ${ }^{-1}$ ) and energy (kcal.100 g $\mathrm{g}^{-1}$ ) from avocados varieties Avocado, Guatemala, Dickinson, and Butter pear and values found in the main tables of food composition.

\begin{tabular}{|c|c|c|c|c|c|c|c|c|}
\hline \multirow[t]{2}{*}{ Nutrients } & \multicolumn{4}{|c|}{ Avocado varieties } & \multirow[t]{2}{*}{ AVERAGE } & \multirow[t]{2}{*}{ TACO } & \multicolumn{2}{|c|}{ Literature } \\
\hline & Avocado & Guatemala & Dickinson & Butter pear & & & TBCAUSP & USDA \\
\hline Moisture & 79.37 & 83.47 & 81.77 & 81.55 & 81.54 & 83.8 & 88.87 & 73.23 \\
\hline Protein & 1.11 & 1.75 & 1.11 & 1.46 & 1.35 & 1.2 & 1.06 & 2.00 \\
\hline Ashes & 0.78 & 0.89 & 0.58 & 0.63 & 0.72 & 0.5 & 0.4 & 1.58 \\
\hline Carbohydrate & 8.90 & 7.30 & 7.39 & 11.54 & 8.78 & 6.00 & 5.65 & 8.53 \\
\hline
\end{tabular}


showed no significant differences between themselves, but they are statistically different from Avocado and Guatemala varieties.

With regard to protein content, the varieties Avocado and Dickinson showed numerically the same protein contents, differing statistically only from Guatemala variety. Similar behavior was found for the lipid content because the varieties Avocado and Dickinson showed no significant differences between themselves and no differences from Guatemala and Butter pear varieties. The variety Avocado showed no significant differences from the other varieties in relation to carbohydrates; however, the varieties Guatemala and Dickinson differed significantly from Butter pear variety.

Salgado et al. (2008) studied the effect of the consumption of avocado meal in Wistar rats. The diet with $15 \%$ of avocado meal was more effective in reducing serum total and LDL cholesterol raising HDL levels. The diet with $25 \%$ of avocado meal was more effective promoting cholesterol excretion. Sitosterol has a structure similar to cholesterol, and its performance is related to intestinal inhibition of total plasma cholesterol absorption and reduction of the hepatic cholesterol synthesis.

In New Zealand, cold-pressed avocado oil has shown high concentrations of chlorophyll (40-60 $\left.\mu \mathrm{g} \cdot \mathrm{g}^{-1}\right)$ and carotenoids, especially lutein $\left(3.2 \mu \mathrm{g} \cdot \mathrm{g}^{-1}\right)$; however, this value may be lower than $1 \mu \mathrm{g} \cdot \mathrm{g}^{-1}$ or higher than $5 \mu \mathrm{g} \cdot \mathrm{g}^{-1}$, depending on the cultivar (REQUEJO-JACKMAN et al., 2005). In cold-pressed olive oil (similarly to the extraction of avocado oil), the lutein concentrations ranged from 0.2 to $3.9 \mu \mathrm{g} \cdot \mathrm{g}^{-1}$ (PSOMIADOU; TSIMIDOU, 2001).

The consumption of carotenoids may bring health benefits because lutein is related to reduction of macular degeneration due to aging ( $\mathrm{KOH}$ et al., 2004). In the market, this type of oil has high added value and is mainly used in cooking. In this case, the concentration and nature of the oils are important determinants of quality and therefore marketing.

To assess the interdependence between nutrient variables, the correlation matrix was calculated from staggered data. Vekiari et al. (2004) conducted a study on the relationship between moisture content, protein, carbohydrates, lipids, and fatty acids in three cultivars using the technique of main component analysis.

Table 3 shows the correlation coefficients (with rates higher than 0.70 , statistically significant above the $95 \%$ confidence interval) of nutrients in the four varieties of avocado analyzed. It appears that: Protein-Moisture, Energy-Lipids, and Chlorophyll-Carotenoids show a positive correlation. Negative correlations are observed for: Energy-Moisture, Energy-Protein, Carotenoids-Lipids, Chlorophyll-Lipids, Chlorophyll-Ashes, Carotenoids-Energy, and Chlorophyll-Energy.

The high degree of positive correlation between energy and lipids and negative between protein and energy indicate that the energy value of avocados has positive contribution from the lipid content and that variable protein contributes negatively to the energy value. The high energy value of the avocado is due to its high lipid content. Since avocado has high fatty acids content in the pulp, the positive correlation clearly shows an association with the energy value. A non-significant correlation between energy and carbohydrates (results not shown) suggests that the energy value is not correlated to the nutrient carbohydrate.

The negative correlation of Carotenoids-Lipids, ChlorophyllLipids, Carotenoids-Energy, and Chlorophyll-Energy indicates the energy and lipid values decrease with the increase of the carotenoids and chlorophyll values.

Table 3. Correlation coefficients of nutrients of Avocado, Guatemala, Dickinson, and Butter pear varieties.

\begin{tabular}{lc}
\hline \multicolumn{1}{c}{ Nutrients } & Correlation coefficient \\
\hline Protein-moisture & 0.7936 \\
Energy-moisture & -0.7887 \\
Energy-protein & -0.8335 \\
Energy-lipids & 0.9114 \\
Carotenoids-lipids & -0.9935 \\
Chlorophyll-lipids & -0.9951 \\
Chlorophyll-ashes & -0.8327 \\
Carotenoids-energy & -0.9521 \\
Chlorophyll-energy & -0.8989 \\
Chlorophyll-carotenoids & 0.9861 \\
\hline
\end{tabular}

Table 2. Proximate composition ( $\left.\mathrm{g} .100 \mathrm{~g}^{-1}\right)$, energy (kcal.100 g $\mathrm{g}^{-1}$ ), and contents of carotenoids and chlorophyll (mg.mL $\mathrm{mL}^{-1}$ extract) of cultivars Avocado, Guatemala, Dickinson, and Butter pear.

\begin{tabular}{|c|c|c|c|c|c|}
\hline \multirow[t]{2}{*}{ Nutrients } & \multicolumn{4}{|c|}{ Avocado varieties } & \multirow[t]{2}{*}{$\rho^{*}$} \\
\hline & Avocado & Guatemala & Dickinson & Butter pear & \\
\hline Moisture & $79.37^{c}$ & $83.47^{\mathrm{a}}$ & $81.77^{\mathrm{b}}$ & $81.55^{\mathrm{b}}$ & $<0.001$ \\
\hline Protein & $1.11^{\mathrm{b}}$ & $1.75^{\mathrm{a}}$ & $1.11^{\mathrm{b}}$ & $1.46^{\mathrm{a} . \mathrm{b}}$ & 0.0257 \\
\hline Lipids & $10.15^{\mathrm{a}}$ & $7.42^{\mathrm{b}}$ & $9.14^{\mathrm{a}}$ & $4.80^{c}$ & $<0.001$ \\
\hline Ashes & $0.78^{\mathrm{a} . \mathrm{b}}$ & $0.89^{\mathrm{a}}$ & $0.58^{\mathrm{b}}$ & $0.63^{\mathrm{a} . \mathrm{b}}$ & 0.0395 \\
\hline Carbohydrate & $8.90^{\mathrm{a} . \mathrm{b}}$ & $7.30^{\mathrm{b}}$ & $7.39^{\mathrm{b}}$ & $11.54^{\mathrm{a}}$ & 0.0032 \\
\hline Carotenoids & $1.72^{\mathrm{a}}$ & $4.09^{\mathrm{a}}$ & $2.61^{\mathrm{a}}$ & $5.65^{\mathrm{a}}$ & 0.0835 \\
\hline Chlorophyll & $8.09^{\mathrm{a}}$ & $12.39^{\mathrm{a}}$ & $8.85^{\mathrm{a}}$ & $16.39^{\mathrm{a}}$ & 0.2516 \\
\hline
\end{tabular}

${ }^{*}$ Analysis of variance. 
Chlorophyll and carotenoids are fat-soluble pigments and are found in oil extracted from avocado (ASHTON et al., 2006); however, they showed no positive correlation with respect to lipids, and due to their absence of energy value, they showed a negative correlation with this parameter. The negative correlation of pigments with lipids may be associated with its function in the fruit.

Two main components were extracted from the entire data set, explaining $89.7 \%$ of the variance (Figure 1). The first main component, explaining $63.8 \%$ of the statistical variance, is characterized by high positive values for lipids and energy value and by negative values for carotenoids and chlorophyll. This component can be correlated with the nutritional components of greatest relevance of the avocado varieties indicating that these parameters correlate with each other and define the overall fruit quality. The second main component explains $25.9 \%$ of the variance with high positive values for moisture and ash, low contribution to protein, and negative value for carbohydrates (Table 4).

Table 5 presents the weights and variances of the main components of the four varieties of avocados analyzed. The values found show that the varieties Avocado and Dickinson correlate more with the first main component of Guatemala and Butter pear varieties, which show very different values from those of the two main components.

Figure 1 can be divided into three groups according to the avocado variety. The varieties Avocado and Dickinson are grouped together and are characterized by the contributions of lipids, energy value, and chlorophyll and carotenoid pigments. Lipids are the first main component.

The varieties Guatemala and Butter pear are located in the second and third quarters, respectively but distant from the variables. It is possible to infer that the parameters lipids, energy,

Table 4. Weights and variances of the main components of nutrients of Avocado, Guatemala, Dickinson, and Butter pear varieties.

\begin{tabular}{|c|c|c|}
\hline \multirow[t]{2}{*}{ Nutrients } & \multicolumn{2}{|c|}{ Main components } \\
\hline & 1 & 2 \\
\hline Moisture (g. $\left.100 \mathrm{~g}^{-1}\right)$ & -0.2906 & 0.4334 \\
\hline Protein $\left(\mathrm{g} .100 \mathrm{~g}^{-1}\right)$ & -0.3562 & 0.3877 \\
\hline Lipids (g.100 g-1) & 0.4272 & 0.1813 \\
\hline Ashes $\left(\mathrm{g} .100 \mathrm{~g}^{-1}\right)$ & 0.0181 & 0.5285 \\
\hline Carbohydrates (g. $\left.100 \mathrm{~g}^{-1}\right)$ & -0.2112 & -0.5481 \\
\hline Energy Value (kcal.100 g-1) & 0.4338 & -0.0920 \\
\hline Carotenoids (mg.mL $L^{-1}$ extract) & -0.4366 & -0.1101 \\
\hline Chlorophyll (mg.mL $\mathrm{mL}^{-1}$ extract) & -0.4271 & -0.1692 \\
\hline
\end{tabular}

Table 5. Weights and variances of the main components of Avocado, Guatemala, Dickinson, and Butter pear varieties.

\begin{tabular}{lrr}
\hline \multirow{2}{*}{ Variety } & \multicolumn{2}{c}{ Main components } \\
\cline { 2 - 3 } & \multicolumn{1}{c}{1} & \multicolumn{1}{c}{2} \\
\hline Avocado & 2.8004 & -0.4149 \\
Guatemala & -1.4969 & 2.2827 \\
Dickinson & 1.5260 & -0.1621 \\
Butter pear & -2.8294 & -1.7057 \\
\hline
\end{tabular}

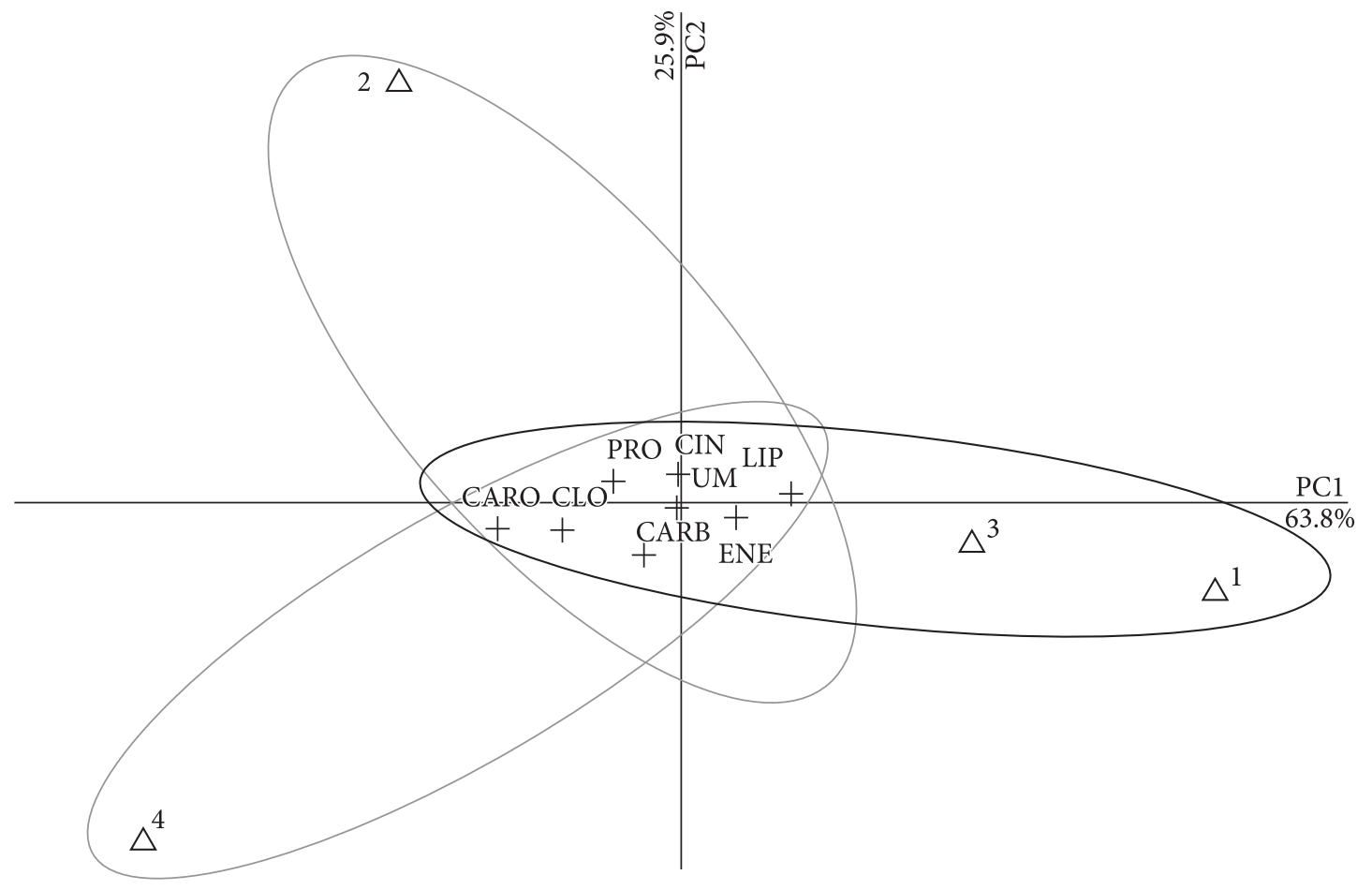

Figure 1. First and second main components of Avocado, Guatemala, Dickinson, and Butter pear varieties. $\Delta 1)$ Avocado, $\Delta 2)$ Guatemala, $\Delta 3)$ Dickinson, $\Delta 4)$ Butter pear. PC - Main component. 
chlorophyll, and carotenoids affect mainly the overall quality of variety Dickinson since it has values that are closer to the first main component when compared to the other varieties.

\section{Conclusion}

The avocados evaluated are mainly correlated with each other by the lipid content and therefore by the high energy content.

Moreover, it could be inferred that the variety Dickinson is the most affected by the parameters evaluated in terms of overall quality.

The varieties Avocado and Dickison are an alternative to oil extraction due to their high lipid content in the pulp with great commercial potential to be exploited. In Brazil, most of the production corresponds to small farmers, usually those who practice subsistence farming. In this case, it leads to waste since usually not all products are sold. To reduce waste, methods for extracting oil in a simple and inexpensive way can be developed, such as aqueous extraction, thus avoiding waste and increasing farmers' income.

\section{References}

AGRIANUAL: Anuário da Agricultura Brasileira. São Paulo: FNP Consultoria e AgroInformativos, 2009. 496 p.

AHMED, E. M.; BARMORE, C. R. Avocado. In: NAGY, S.; SHAW, P. E.; WARDOWSKI, W. F. (Ed.). Fruits of tropical and subtropical origin: composition, properties and uses. Lake Alfred: AVI Publishing, 1990.

ASHTON, O. B. O. et al. Pigments in avocado tissue and oil. Journal of Agricultural and Food Chemistry, v. 54, p. 10151-10158, 2006. PMid:17177553. http://dx.doi.org/10.1021/jf061809j

ASSOCIATION OF OFFICIAL ANALYTICAL CHEMISTS - AOAC. Official methods of analysis of the Association of Official Analytical Chemists. 16th. ed. Washington: AOAC, 1995. 2 v.

BLEINROTH, E. W.; CASTRO, J. V. Matéria-prima. In: TEIXEIRA, C. G. et al. Abacate: cultura, matéria-prima, processamento e aspectos econômicos. Campinas: ITAL, 1992.

CANTO, W. L.; SANTOS, L. C.; TRAVAGLINI, M. M. E. Óleo de abacate: extração, usos e seus mercados atuais no Brasil e na Europa. Campinas: ITAL, 1980.

DANIELI, F. O óleo de abacate (Persea americana Mill) como matéria-prima para a indústria alimentícia. 2006. 47 f. Dissertação (Mestrado em Ciência e Tecnologia de Alimentos)-Universidade de São Paulo, Piracicaba, 2006.

FAVIER, J. C. et al. Repertório Geral dos alimentos: tabela de composição. 2. ed. São Paulo: Roca, 1999.

FUKUZAWA, K. et al. Rate constants for quenching singlet oxygen and activities for inhibiting lipid peroxidation of carotenoids and $\alpha$-tocopherol in liposomes. Lipids, v. 33, p. 751-756, 1998. PMid:9727604. http://dx.doi.org/10.1007/s11745-998-0266-y

HICKS, K. B.; MOREAU, R. A. Phytosterols and phytostanols: functional food cholesterol busters. Food Technology, v. 50, p. 63-67, 2001.

KAMAL-ELDIN, A.; APPELQVIST, L. A. The chemistry and antioxidant properties of tocopherols and tocotrienols. Lipids, v. 31, p. 671-701, 1996. PMid:8827691. http://dx.doi.org/10.1007/ BF02522884

KLUGE, R. A. et al. Inibição do amadurecimento de abacate com 1-meticiclopropeno. Pesquisa Agropecuária Brasileira, v. 37, n. 7, 2002. http://dx.doi.org/10.1590/S0100-204X2002000700001

KOLLER, O. C. Abacaticultura. Porto Alegre: UFRGS, 1992. 138 p.

$\mathrm{KOH}, \mathrm{H}$. H. et al. Plasma and macular responses to lutein supplement in subjects with and without age-related maculopathy: a pilot study. Experimental Eye Research, v. 79, p. 21-27, 2004. PMid:15183097. http://dx.doi.org/10.1016/j.exer.2004.03.001

LAW, M. R. Plant sterol and stanol margarines and healt. British Medical Journal, v. 320, 2000.

LICHTENTHALER, H. K. Chlorophylls and carotenoids: Pigments of photosynthetic biomembranes. Methods Enzymol, v. 148, p. 350-382, 1987. http://dx.doi.org/10.1016/0076-6879(87)48036-1

LU, Q. Y. et al. Inhibition of prostate cancer cell growth by an avocado extract: Role of lipid-soluble bioactive substances. Journal of Nutritional Biochemistry, v. 16, p. 23-30, 2005. PMid:15629237. http://dx.doi.org/10.1016/j.jnutbio.2004.08.003

MARANCA, G. Fruticultura comercial manga e abacate. São Paulo: Nobel, 1980.

MARTÍNEZ-ROMERO, D. et al. 1-Methylcyclopropene increases storability and shelf life in climacteric and nonclimacteric plums. Journal of agricultural and food chemistry, v. 51, 2003.

MCCUNE, B.; MEFFORD, M. J. PC-ORD Multivarate analysis of ecological data. version 3.0. Oregon: MJM Software Design, 1997.47 p.

MURCIA, M. A.; JIMÉNEZ, A. M.; MARTÍNEZ-TOMÉ, M. Evaluation of the antioxidant properties of Mediterranean and tropical fruits compared with common food additives. Journal of Food Protection, v. 64, p. 2037-2046, 2001. PMid:11770635.

OLAETA, J. A. C.; UNDURRAGA, P. M. Estimacion del indice de madurez en paltos. In: KUSHWAHA, L.; SERWATOWSKI, R.; BROOK, R. (Eds.). Harvest and postharvest technologies for fresh fruits and vegetables: proceedings of the international conference. Guanajuato: ASAE, 1995. p. 421-426.

OLIVEIRA, C. C. A. et al. Avaliação das características sensoriais de polpada de abacate. In: SIMPÓSIO INTERNACIONAL DE INICIAÇÃO CIENTÍFICA DA UNIVERSIDADE DE SÃO PAUlO, 2., 2003, Piracicaba. Anais... São Paulo: USP, 2003. 1 CD-ROON.

PEIXOTO, A. M. et al. (Coords.). Enciclopédia Agrícola Brasileira - EAB. São Paulo: EdUSP, 1995.

PSOMIADOU, E.; TSIMIDOU, M. Pigments in Greek virgin olive oils: Occurrence and levels. Journal of the Science of Food and Agriculture, v. 81, n. 7, p. 640-647, 2001. http://dx.doi.org/10.1002/ jsfa.859

REBOLLO, A. J. G. et al. Effects of comsumption of meat product rich in monounsaturated fatty acids (the ham from the Iberian pig) on plasma lipids. Nutrition Research, v. 18, 1998.

REQUEJO-JACKMAN, C. et al. The good oil on avocado cultivarssA preliminary evaluation. Orchardist, v. 78, n. 10, p. 54-58, 2005.

SALDEEN, K.; SALDEEN, T. Importance of tocopherols beyond a-tocopherol: evidence from animal and human studies. Nutrition Research, v. 25, p. $877-889,2005$. http://dx.doi.org/10.1016/j. nutres.2005.09.019

SALGADO, J. M. Alimentos Inteligentes. São Paulo: Editora Prestígio, 2005. 
SALGADO, J. M. et al. Efeito do abacate (Persea americana Mill) variedade hass na lipidemia de ratos hipercolesterolêmicos. Ciência e Tecnologia de Alimentos, v. 28, n. 4, 2008.

STATISTICAL ANALISYS SYSTEM INSTITUTE - SAS. SAS Software. version 9.1. Cary: SAS Institute Inc., 1999.

SOARES, S. E.; MANCINI FILHO, J.; DELLA MODESTA, R. C. Sensory detection limits of avocado oil in mixtures with olive oil. Revista Española de Ciencia y Tecnologia de Alimentos, v. 32, n. 5, 1992.

SCHULER, P. Natural antioxidants exploited commercially. In: HUDSON, B. J. F. (Ed.). Food antioxidants. New York: Elsevier Science Publishers Ltd., 1990. p. 99-171.

TANGO, J. S. T.; CARVALHO, C. R. L.; SOARES, N. B. Physical and chemical characterization of avocado fruits aiming its potencial for oil extraction. Revista Brasileira de Fruticultura, v. 26, n. 1, 2004.

TANGO, J. S.; TURATTI, J. M. Óleo de abacate. In: TEIXEIRA, C. G. et al. Abacate: cultura, matéria-prima, processamento e aspectos econômicos. Campinas: ITAL, 1992.

TEIXEIRA, C. G. et al. Abacate: cultura, matéria-prima, processamento e 78 aspectos econômicos. 2. ed. ver. e ampl. Campinas: ITAL, 1992. (Série frutas tropicais, n. 8).
TUCUNDUVA, O. S. Tabela de composição de alimentos: suporte para decisão nutricional. 2. ed. São Paulo: Coronário, 2002.

TURATTI, J. M.; CANTO, W. L. Insaponificáveis do óleo de abacate. Boletim ITAL, v. 22, n. 3, 1985.

UNITED STATES. Department of Agriculture - USDA. National Nutrient Database for Standard Reference. Disponível em: $<$ http://www.nal.usda.gov/fnic/foodcomp/search $>$. Acesso em: 10 jun. 2010.

UNIVERSIDADE DE SÃO PAULO - USP. Departamento de Alimentos e Nutrição Experimental. Tabela brasileira de composição de alimentos - TBCAUSP. versão 5.0. Disponível em: <http://www. fcf.usp.br/tabela>. Acesso em: 10 jun. 2010.

UNIVERSIDADE ESTADUAL DE CAMPINAS - UNICAMP. Tabela brasileira de composição de alimentos - TACO. Versão 2. 2. ed. Campinas: UNICAMP/NEPA, 2006.

VEKIARI, S. A. et al. Variation in the composition of Cretan avocado cultivars during ripening. Journal of the Science of Food and Agriculture, v. 84, p. 485-492, 2004. http://dx.doi.org/10.1002/ jsfa.1595

VIEIRA, G.; VIÉGAS, P. A. Fisiologia e manejo pós-colheita do abacate. Informe Agropecuário, v. 17, n. 179, 1994. 